\title{
Developing of Sustainable Supply Chain Management Indicators in Construction
}

\author{
Ieva Cataldo*, Nerija Banaitienè, and Audrius Banaitis \\ Department of Construction Management and Real Estate, Faculty of Civil Engineering, Vilnius \\ Gediminas Technical University, Saulètekio al. 11, LT-10223 Vilnius, Lithuania
}

\begin{abstract}
Most of the existing supply chain management methods and systems are being transferred to construction regardless of the specifics of companies in the construction sector. Numerous complex factors such as ecological, social and economic are required for the continuous evaluation in the modern management of construction sector. The provided studies and the research to examine sustainable supply chain management in construction sector from a holistic perspective, concentrating on mostly long-term sustainable decision-making by the construction company rather than being centered only on the supply chain management for construction projects. This paper identifies a list of sustainability indicators for examining the supply chains of construction companies. Those indicators were categorized and assigned to one or a couple groups by reviewing their use in the previous literature agreeing to the reasoning to way better reflect the SSCM principle of their use in construction companies. The use of indicators can help develop strategies for the construction sector for sustainable policy makers and construction company managers.
\end{abstract}

\section{Introduction}

The application of the sustainable supply chain management (SSCM) in construction companies reduces environmental impact, reduces the risk of failure and increases the competitiveness of construction companies. Innovations in the construction sector are accepted slowly. Researchers studying the supply chain and its management state that the performance of supply chains (local and holistic) can be better if the conjunctural relations and processes between companies are actively managed $[1,2,3]$. The management aspect and its importance is often overlooked; it also determines the added value of a construction project.

The construction supply chain includes contractors, manufacturers, building material suppliers, builders and developers, as well as people, carriers, and other intermediaries providing warehousing services, as well as the customer (client). All entities of the construction supply chain (SC) are interconnected by links of finance, information and materials, but not all of them are mandatory in every part of the chain [4]. The actions of the entity and the need of customers determine the structure of the construction supply chain. The supply chain is being treated as a chain of events and cannot be observed for a single

*Corresponding author: ieva.cataldo@vilniustech.lt 
step or stage; the SC must be treated as a network [5]. A builder can obtain materials from multiple suppliers at once and transfer his product to multiple resellers and intermediaries.

SSCM emphasizes a wider range of actions for SC managers and companies as this requires the development and implementation of policies to improve the environmental, economic and social governance of partners. In general, the SSCM covers four areas: (1) information, product, financial management; (2) management of economic and social factors; (3) technology and new project management; and (4) stakeholder governance.

This paper aims to identify a list of sustainability indicators for examining the supply chains of construction companies.

\section{Literature review}

The main task of construction supply chain management is to coordinate and integrate material, financial and information flows between customers, suppliers, builders, contractors, material manufacturers, retail and wholesale companies, to control and automate construction and logistics processes. The use of one or more integrated computer systems and the standardization of processes allows construction companies to save time, avoid mistakes, reduce staff numbers and increase the efficiency of the construction process. Ensuring a smooth process of design, construction, planning the logistics, ordering materials and production reduces the sum of workers and specialists needed, shortens construction time and optimizes costs [6].

Most supply chains (not only in the construction field) are commercial which means that they are successful when the desired profitability of the supply chain is achieved [7]. For a construction supply chain to be successful at all stages, supply chain management needs to be assessed. Understanding that all flows in the construction supply chain are cost driven, it can be concluded that effective management of construction flows and coordination of the movement of those flows is an essential condition for success [8].

Supply chain management in the construction sector can address intertwined organizational challenges and offer effective management strategies for potential barriers at any stage of construction [9]. Reviewing the construction supply chain management structure, three main parts can be identified that are indispensable for successful supply chain operations: management elements, business processes and supply chain structure (Fig. 1) [10].

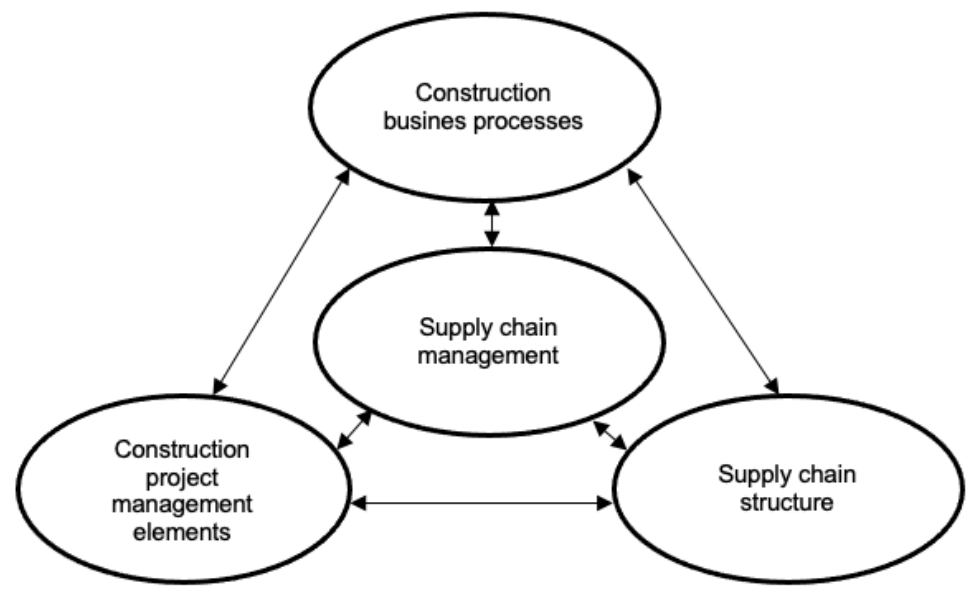

Fig. 1. Simple structure of supply chain management [10]. 
According to Konovalenko and Ludwig [10], the definition of SCM covers all the main activities of the construction process that create added value for construction companies starting with the exterior and interior design of a building, project planning to the construction and finishing the construction project in time. The main goal in the supply chain of builders and designers is to increase the operation rates, speed up the implementation of construction projects and reduce inventories.

Information systems help to track and transfer customer needs at different levels of the chain in order to minimize the cost of building materials and inventory in the supply chain [11]. All branches of the general construction industry scheme are interconnected and operate as a kind of ecosystem.

Most studies emphasize the need to move towards a sustainable approach in project management, especially in the construction sector. Shen et al. describes the reasons why sustainability should be included in the construction management plan, including competitive activities [12].

Further research of a construction supply chain requires a better understanding of potential threats. According to Boone et al. [13] the diversity of external and internal environmental factors leads to an increase risk in supply chain. Globalization, changes in global policies and other macro-environmental trends increase the risk of challenges (endless pressure to improve efficiency and reduce operating costs as much as possible) or emerging problems. The main objective of risk management is to monitor, control, and assess the supply chain risks that could ensure the maximum profitability growth and continuity in the future in the supply chain $[13,14]$. As it is shown in the picture below (Fig. 2), lack of ontime supply of materials and machinery at the right place and time is the most important cause of construction supply chain threats and failures. In order to reduce the consequences of risk and protect the value of the business and the brand the construction organization must decide what it can do in this competitive and complex business environment.

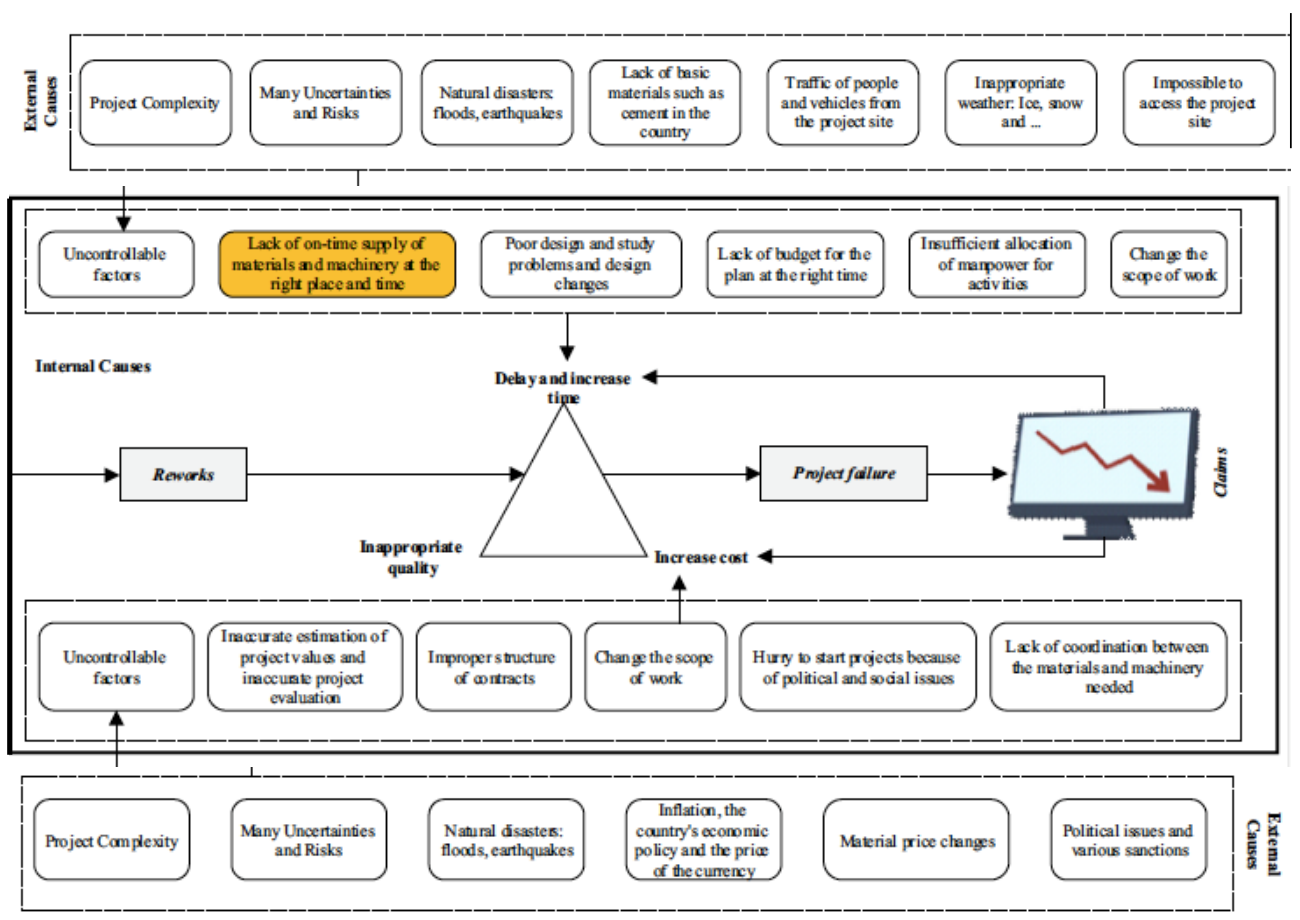

Fig. 2. Construction supply chain threat plan (compiled by the authors according to [14]). 
In order to collaborate and manage the supply chain in high-risk situations, the construction company's users and suppliers often come together [15]. Supply chain stability and efficient operation, taking advantage of the company's new opportunities, is reflected in the assured ability to manage the entire logistics process and its participants: costs, products, suppliers, warehousing [16].

It is necessary to identify potential risks followed by risk and consequence assessment in an attempt to flawlessly implement the supply chain risk management problem in the construction sector between which there is sequence and close interdependence. Finally, the right strategy needs to be chosen [17]. Risk monitoring is one of the last steps in the most important and essential stages of the risk management process in the supply chain. It must ensure the continued operation of the construction company without foreseeable hazards or disruptions.

\section{Sustainability indicators in construction using SSCM}

To address the sustainability issues in the construction sector, it is necessary to understand the relevant indicators. Specific indicators that determine the success of the project are usually used in the construction projects [18].

SSCM integrates sustainability goals and requirements defined by the management of the construction company, external stakeholders, suppliers and customers. In order for the supply chain to be sustainable, some goals like environmental, social, ethical and economic must be achieved by all members of the construction supply chain [19]. A useful perspective could be product life-cycle analysis, which allows the identification of the environmental impact of an item all through its life cycle, starting the stage of designing the product ending the utilization of the product or building $[19,20]$. The choice of suppliers of construction materials may be based on various criteria such as environmental, which construction companies must set in conformity with their strategic objectives, policies and regulatory standards [21]. For environmental performances monitoring reasons construction companies could select their suppliers based on environmental criteria or set some policies to be met by their suppliers in order to have business together [20].

Most research related to SSCM relates to the three main pillars of sustainability, which in the Brundtland Report are defined as environmental, economic and social pillars, mostly known as the Triple Bottom Line. These pillars were examined by the SSCM by Carter and Rogers [22] and provided the most frequently cited definitions of the SSCM. However, there are still few tools to evaluate sustainability of a construction company based on the Triple Bottom Line.

Relevant indicators need to be understood in order to address the sustainability of construction. As the basic $3 R s$ system of Recycle, Reduce and Remanufacture are the main requirement for GSM (Global Supply Chain Management) analysis, Moldan and Dahl contend that not all markers are similarly accurate and quantified [23]. According to Stanitsas et al. [18], before examining the supply chains of construction companies, first it is necessary to divide sustainability indicators into several groups (Fig. 3).

The following groups (economic, social and environmental) make it easier to disaggregate the indicators that are relevant in the sustainable supply chain stages of the construction sector. Triple Bottom Line aspects can be better understood when the SSCM scenario is predictable (pessimistic, realistic, and optimistic). In this article the scenario will not be assessed. Some indicators apply not only to one but to several groups at once. 


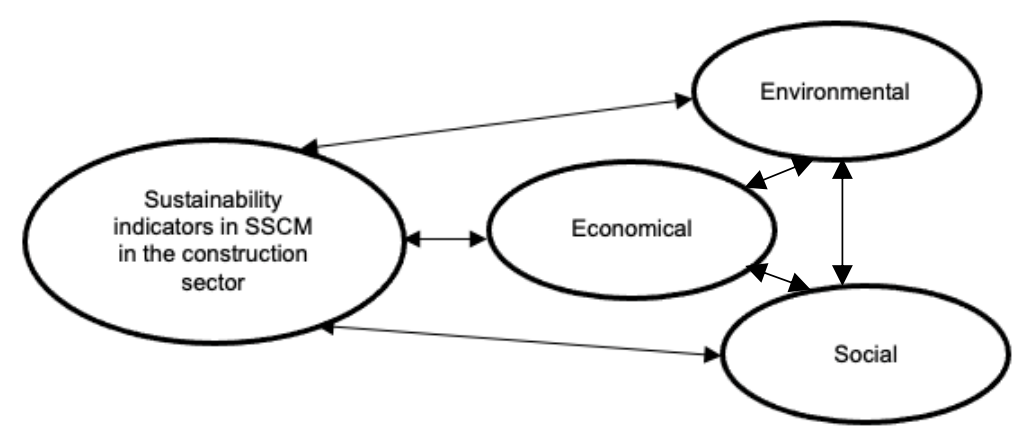

Fig. 3. Groups of Sustainability Indicators in SSCM (compiled by the authors).

Based on the examination of the literature [18, 24-36], it is apparent that there are plenty of indicators with the potential to affect sustainable supply chains in construction. The identified sustainability indicators for examining the supply chains of construction companies are listed in Tables 1, 2 and 3.

Table 1. Economic sustainability indicators in construction companies (compiled by the authors).

\begin{tabular}{|c|c|c|}
\hline Index & Indicator & $\begin{array}{c}\text { Which groups are } \\
\text { suitable for (economic } \\
\text { - ECO, social - SOC, } \\
\text { environmental - ENV) }\end{array}$ \\
\hline ECO 1 & Financial, economic execution of a construction project & ECO \\
\hline $\mathrm{ECO} 2$ & Economic and political stability of the sector & $\mathrm{ECO}, \mathrm{SOC}$ \\
\hline $\mathrm{ECO} 3$ & Stakeholder participation in the construction project & $\mathrm{ECO}, \mathrm{SOC}$ \\
\hline $\mathrm{ECO} 4$ & $\begin{array}{l}\text { Innovation management, development of new products and } \\
\text { tools }\end{array}$ & $\mathrm{ECO}, \mathrm{SOC}$ \\
\hline ECO 5 & Targeted marketing and benefits of a construction company & ECO \\
\hline ECO 6 & Effective control of construction projects & $\mathrm{ECO}$ \\
\hline $\mathrm{ECO} 7$ & The strategy of best practice, effective strategic planning & ECO, SOC, ENV \\
\hline ECO 8 & Efficient allocation of construction resources & ECO \\
\hline ECO 9 & $\begin{array}{l}\text { Management of customer relations, accessibility of necessary } \\
\text { contacts }\end{array}$ & $\mathrm{ECO}, \mathrm{SOC}$ \\
\hline ECO 10 & Scope management facing the relentless change & $\mathrm{ECO}$ \\
\hline ECO 11 & $\begin{array}{l}\text { Appropriate ethics of the construction business and } \\
\text { organizational culture }\end{array}$ & $\mathrm{ECO}, \mathrm{SOC}$ \\
\hline ECO 12 & $\begin{array}{lccc}\begin{array}{l}\text { Premises management technologies } \\
\text { improvements in tools and techniques }\end{array} & \text { and } & \text { general } \\
\end{array}$ & ECO \\
\hline ECO 13 & Construction project cost management and resource planning & ECO, SOC, ENV \\
\hline ECO 14 & Cooperation between members of the supply chain & $\mathrm{ECO}, \mathrm{SOC}$ \\
\hline ECO 15 & Emphasis on the project results & $\mathrm{ECO}, \mathrm{SOC}$ \\
\hline ECO 16 & $\begin{array}{l}\text { Development of a project management plan for construction } \\
\text { management activities }\end{array}$ & ECO, SOC, ENV \\
\hline ECO 17 & Ability to pay and affordability & ECO \\
\hline ECO 18 & Targeted incentives for owner and workers & ECO \\
\hline ECO 18 & $\begin{array}{l}\text { Economic and environmental accounting for a construction } \\
\text { project }\end{array}$ & $\mathrm{ECO}, \mathrm{ENV}$ \\
\hline
\end{tabular}




\begin{tabular}{|c|l|c|}
\hline ECO 20 & Effective risk management plan & ECO \\
\hline ECO 21 & Implementation of change management strategy & ECO, SOC, ENV \\
\hline ECO 22 & Effective data processing for decision making tools & ECO, SOC \\
\hline ECO 23 & Bureaucratic rationalization & ECO, SOC \\
\hline ECO 24 & Internationalization of a construction company & ECO \\
\hline
\end{tabular}

Table 2. Environmental sustainability indicators in construction companies (compiled by the authors).

\begin{tabular}{|c|c|c|}
\hline Index & Indicator & $\begin{array}{c}\text { Which groups are } \\
\text { suitable for (economic } \\
\text { - ECO, social - SOC, } \\
\text { environmental - ENV) }\end{array}$ \\
\hline ENV 1 & Environmental education and training for the workers & ENV, SOC \\
\hline ENV 2 & $\begin{array}{l}\text { Sustainable project implementation by managing } \\
\text { construction project stakeholders }\end{array}$ & ENV, SOC \\
\hline ENV 3 & $\begin{array}{l}\text { Reducing environmental impact considering the life-cycle of } \\
\text { construction services, tools and items }\end{array}$ & $\mathrm{ENV}, \mathrm{ECO}$ \\
\hline ENV 4 & Use of sustainable building materials & ENV \\
\hline ENV 5 & Environmental management plan & ENV, SOC \\
\hline ENV 6 & Project biodiversity & ENV \\
\hline ENV 7 & $\begin{array}{l}\text { Suitable and adaptable details and specifications of } \\
\text { environmental design }\end{array}$ & $\mathrm{ENV}, \mathrm{ECO}$ \\
\hline ENV 8 & $\begin{array}{l}\text { Adaptation to catastrophe risk management and the climate } \\
\text { change }\end{array}$ & ENV, SOC, ECO \\
\hline ENV 9 & $\begin{array}{l}\text { Importance of environmental management systems and } \\
\text { policies }\end{array}$ & ENV \\
\hline ENV 10 & Environmental impact assessment project report & ENV, SOC \\
\hline ENV 11 & Construction impact of water quality & ENV, SOC \\
\hline ENV 12 & Environmental responsibility of a construction company & ENV, SOC \\
\hline ENV 13 & $\begin{array}{l}\text { The use latest environmental construction technologies and } \\
\text { methods }\end{array}$ & ENV, ECO, SOC \\
\hline ENV 14 & Sustainable use of natural resources & $\mathrm{ENV}, \mathrm{ECO}$ \\
\hline ENV 15 & Consistent and predictable construction load & ENV \\
\hline ENV 16 & $\begin{array}{l}\text { Ecological efficiency of materials and tools used; energy } \\
\text { efficiency }\end{array}$ & ENV, ECO, SOC \\
\hline ENV 17 & $\begin{array}{l}\text { Renewable energy sources suitable for use, reduction of } \\
\text { fossil fuel }\end{array}$ & $\mathrm{ENV}, \mathrm{ECO}$ \\
\hline
\end{tabular}

Table 3. Social sustainability indicators in the constructional companies (compiled by the authors).

\begin{tabular}{|c|l|c|}
\hline Index & \multicolumn{1}{|c|}{ Indicator } & $\begin{array}{c}\text { Which groups are } \\
\text { suitable for (economic } \\
\text { - ECO, social - SOC, } \\
\text { environmental - ENV) }\end{array}$ \\
\hline SOC 1 & Social responsibility of a construction company & SOC \\
\hline SOC 2 & Financing of social actions, concepts of social justice & SOC, ECO \\
\hline SOC 3 & $\begin{array}{l}\text { Sustainability and organizational culture of construction } \\
\text { companies }\end{array}$ & SOC, ENV, ECO \\
\hline SOC 4 & Socially responsible, ethical work practice & SOC \\
\hline SOC 5 & Sustainable employment, employee satisfaction & SOC, ECO \\
\hline
\end{tabular}




\begin{tabular}{|c|l|c|}
\hline SOC 6 & Community relations and involvement in community issues & SOC, ECO \\
\hline SOC 7 & Respect for human rights and safety & SOC \\
\hline SOC 8 & Employee commitment in the workplace & SOC \\
\hline SOC 9 & Public acceptance of the construction project & SOC \\
\hline SOC 10 & Stakeholder involvement and management & SOC \\
\hline SOC 11 & $\begin{array}{l}\text { Independence of political factors from the construction } \\
\text { project }\end{array}$ & SOC \\
\hline SOC 12 & Social impact reports & SOC \\
\hline SOC 13 & Transparent and competitive procurement processes & SOC, ECO \\
\hline SOC 14 & Friendly relationship between contractor and supplier & SOC, ECO, ENV \\
\hline SOC 15 & $\begin{array}{l}\text { The scope of the construction project and the constraints of } \\
\text { the project are well defined }\end{array}$ & SOC, ECO \\
\hline SOC 16 & A holistic approach to the benefits of a construction project & SOC, ECO \\
\hline SOC 17 & Emphasis is placed on high quality work ethic & SOC \\
\hline SOC 18 & Promoting fair competition & SOC \\
\hline SOC 19 & Implementation of quality management system & SOC \\
\hline SOC 20 & Culture of accountability & SOC \\
\hline SOC 21 & Detailed documentation of construction project contract & SOC \\
\hline SOC 22 & Adaptation to the construction project environment & SOC \\
\hline SOC 23 & Management of the intangible assets & $\begin{array}{l}\text { pracking of the construction project management stages and } \\
\text { processes }\end{array}$ \\
\hline SOC 24 & \\
\hline
\end{tabular}

\section{Discussion}

These indicators listed and analyzed above (economic, environmental and social) for a total of 65 indicators, were compiled and refined according to a list of scientific literature suitable for analyzing sustainable supply chain management in the construction sector. Those indicators were categorized and assigned to one or a couple groups by reviewing their use in the previous literature agreeing to the reasoning to way better reflect the SSCM principle of their use in construction companies (Tables 1, 2 and 3). Column 3 of each table reveals the main relationship between the SSCM of each indicator and the other categories (in environmental, social or economic terms), which is the main criterion for initial classification. Interestingly, most social indicators have a direct link to many management issues, thus reflecting the aspect of sustainable supply chain management [37]. It ought to be noted that the arrange in which the indicators are shown does not reflect their importance.

In analyzing the tables shown above, applicability factors, technical factors and engineering tools are included to the economic side of sustainability. When multi-component productiveness has increased over length of time, a construction project could be considered economically attainable [38]. Quality factors such as value deterioration of the ecological surroundings and damage criterion related to the quality of environmental services are introduced in the environmental feature of the sustainability indicators in the research. Environmental management factors are supply chain practices through which a construction corporation handles the environmental impact of its enterprise actions by supporting a coordinated sustainable planning approach [39]. In the social dimension of management, team factors show how to usefully communicate with the local community and the 
stakeholders about a proposal of a new construction project. Communication and collaboration on the success of a sustainability project highlights the operation and shapes up stakeholder acceptance [38]. These indicators include SSCM values, participation of all the users in the SC, help from the team members, association, attainability of technical materials, natural resources, administrative support, external environment, precise project assignments and development goals. In the construction sector, it is crucially important to select technological systems for an effective multi-criteria task completion.

The main aim of sustainability in construction engineering development is to contribute assistance to local communities that have a positive influence on every single aspect of sustainability in SSCM [40, 41]. To disclose the sustainability potential of the end result, research is needed before the first construction phase of the project.

\section{Conclusions}

The methodology presented in this article provides tools solving SSCM problems in construction sector. This approach could be used for the life-cycle based optimization model of construction companies, software implementations, etc.

The sustainability indicators were divided into three groups such as social (governance), economic and environmental. They were better understood when the SSCM scenario is predictable (pessimistic, realistic, and optimistic). The breakdown of indicators according to the SCM sustainability scenario and their in-depth study provides a basis for project managers and researchers to further analyse and study the indicators of projects in the construction engineering. As a result of this study, managers of the construction projects can more easily plan up to date, advanced sustainable approaches in order to achieve sustainability success in innovative projects, taking into account the identified 65 sustainability indicators: social, environmental and economic. In a real-life scenario, the use of indicators can help develop strategies for the construction sector for sustainable policy makers and construction company managers.

For future research, e.g. factor analysis method could be used to investigate the underlying relationship among the identified sustainability indicators to find out the clusters that can better represent all the indicators and a multiple criteria analysis of alternatives in order to examine the supply chains of construction companies.

This research was supported as part of the "Integrating education with consumer behaviour relevant to energy efficiency and climate change at the universities of Russia, Sri Lanka and Bangladesh (BECK)" Project No. 598746-EPP-1-2018-1-LT-EPPKA2-CBHE-JP. Grant Agreement No. 2018-2489/001001, which has received funding from the Erasmus+ Programme of the European Union. The European Commission support for the production of this publication does not constitute an endorsement of the contents which reflects the views only of the authors, and the Commission cannot be held responsible for any use which may be made of the information contained therein.

\section{References}

1. S. Baldi, H. Borgman, A case study of the automotive industry, in $14^{\text {th }}$ Bled Electronic Commerce Conference, Slovenia (2001)

2. C. Chandra, S. Kumar, Supply chain management in theory and practice: A passing fad or a fundamental change?, Ind. Manage. Data Syst. 100, 100-114 (2000)

3. J.T. Mentzer, W. Dewitt, J.S. Keebler, S. Min, N.W. Nix, C.D. Smith, Z.G. Zacharia, Defining supply chain management, J. Bus. Logist. 22, 1-25 (2001) 
4. G. Fliedner, CPFR: An emerging supply chain tool, Ind. Manage. Data Syst. 103, 14-21 (2003)

5. S. Li, B. Ragu-Nathan, T.S. Ragu-Nathan, S.S. Rao, The impact of supply chain management practices on competitive advantage and organizational performance, Omega-Int. J. Manage. Sci. 34, 107-124 (2006)

6. E. Monk, B. Wagner, Concepts in enterprise resource planning (Cengage Learning, Boston, 2012)

7. A. Brint, A. Genovese, C. Piccolo, Reducing data requirements when selecting key performance indicators for supply chain management: The case of multinational automotive component manufacturer, Int. J. Prod. Econ. 233, 107967 (2021)

8. D.M. Lambert, Supply chain management: Processes, partnerships, performance (Supply Chain Management Institute, Sarasota, Florida, 2008)

9. M.W. Lewis, C. Andriopoulos, W.K. Smith, Paradoxical leadership to enable strategic agility, Calif. Manage. Rev. 56, 58-77 (2014)

10. I. Konovalenko, A. Ludwig, Event processing in supply chain management - the status quo and research outlook, Comput. Ind. 105, 229-249 (2019)

11. M. Pagell, Z.H. Wu, Building a more complete theory of sustainable supply chain management using case studies of 10 exemplars, J. Supply Chain Manag. 45, 37-56 (2009)

12. L.Y. Shen, V.W.Y. Tam, Y.-b. Ji, Project feasibility study: The key to successful implementation of sustainable and socially responsible construction management practice, J. Clean Prod. 18, 254-259 (2010)

13. T. Boone, R. Ganeshan, A. Jain, N.R. Sanders, Forecasting sales in the big supply chain: Consumer analytics in the big data era, Int. J. Forecast. 35, 170-180 (2019)

14. A. RezaHoseini, S. Noori, S.F. Ghannadpour, Integrated scheduling of suppliers and multi-project activities for green construction supply chains under uncertainty, Autom. Constr. 122, 103485 (2021)

15. S. Chopra, P. Meindl, Supply chain management: Strategy, planning, and operation (Prentice Hall, New York, 2001)

16. A. Yousaf, B.S. Talal, R. Obaid, Integration of IoT technologies in construction chain networks; CPEC a case in point, Sustainable Oper. Comput. 1, 28-34 (2020)

17. F. Cucchiella, I. D’Adamo, Issue on supply chain if renewable energy, Energy Conv. Manag. 76, 774-780 (2013)

18. M. Stanitsas, K. Kirytopoulos, V. Loepoulos, Integrating sustainability indicators into project management: The case of construction industry, J. Clean Prod. 279, 123774 (2021)

19. M.M.C. Fritz, Sustainable supply chain management, in L. Filho et al., (eds) Responsible consumption and production, Encyclopedia of the UN Sustainable Development Goals (Springer, Cham, 2019)

20. C.Y. Wong, C.W. Wong, S. Boonitt, Integrating environmental management into supply chains, Int. J. Phys. Distrib. Logist. Manag. 45, 43-68 (2015)

21. J.P. Schöggl, R.J. Baumgartner, D. Hofer, Improving sustainability performance in early phases of product design: A checklist for sustainable product development tested in the automotive industry, J. Clean Prod. 140, 1602-1617 (2017)

22. C.R. Carter, D.S. Rogers, A framework of sustainable supply chain management: Moving toward new theory, Int. J. Phys. Distrib. Logist. Manag. 38, 360-387 (2008) 
23. B. Moldan, A.L. Dahl, Editorial, Ecol. Indic. 12, 1-3 (2012)

24. J.L.N. Zon, C.J. Loepoldino, L.H. Yamane, R.R. Siman, Waste pickers organizations and municipal selective waste collection: Sustainability indicators, Waste Manage. 118, 219231 (2020)

25. I. Gunnasdottir, B. Davidsdottir, E. Worrell, Review of indicators for sustainable energy development, Renew. Sust. Energ. Rev. 133, 110294 (2020)

26. E. Yadegaridehkordi, M. Hourmand, M. Nilashi, E. Asolami, Assesment of sustainability indicators for green builing manufacturing using fuzzy multi-criteria making approach, J. Clean Prod. 277, 122905 (2020)

27. A. Merino-Saum, P. Halla, V. Superti, A. Boesch, C.R. Binder, Indicators for urban sustainability: Key lessons from systematic analysis of 67 measurement initiatives, Ecol. Indic. 119, 106879 (2020)

28. S.F. Salami, A.D. Isah, I.B. Muhammad, Critical indicators of sustainability for mixeduse buildings in Lagos, Nigeria, Environ. Sust. Indic. 9, 1001101 (2021)

29. J. Reid, M. Rout, Developing sustainability indicators - The need for radical transparency, Ecol. Indic. 110, 105941 (2020)

30. D.B. Huertas, F. Farinha, M.J. Oliveira, E. Silva, Comparison of artificial intelligence algorithms to estimate sustainability indicators, Sust. Cities Soc. 63, 102430 (2020)

31. H. Wang, X. Lu, C.Sheng, W. Cui, General frame for arbitrary 3R subproblems based on the POE model, Robot. Auton. Syst. 105, 138-145 (2018)

32. Y. Shuanggui, J. Baoguo, L. Chun, The tentative idea of energy recovery based on "3R" principle, Procedia Engineering. 21, 1188-1192 (2011)

33. B. Huang, X. Wang, Y. Geng, R. Bleischtwitz, Construction and demolition waste management in China through the 3Rprinciple, Resour. Conserv. Recycl. 129, 36-44 (2018)

34. I. Gunnasdottir, B. Davidsdottir, E. Worrell, It is best to ask: Designing a stakeholdercentric approach to selecting sustainable energy development indicators, Energy Res. Soc. Sci. 45, 101968 (2021)

35. S. Quamar, M. Al-Kindi, Renewability and sustainability: Current status and future prospects, Encyclopedia of Renewable and Sustainable Materials. 1, 717-730 (2020)

36. Y. Shi, J. Xu, BIM-based information system for econo-enviro-friendly end-of-life disposal of construction and demolition waste, Autom. Constr. 125, 103611 (2021)

37. S. Yildiz, S. Kivrak, A.B. Gultekin, G. Arslan, Built environmental design - social sustainability relation in urban renewal, Sust. Cities Soc. 60, 102173 (2020)

38. Q. Zhang, B.L. Oo, B.T.H. Lim, Drivers, motivations, and barriers to the implementation of corporate social responsibility practices by construction enterprises: A review, J. Clean Prod. 210, 563-584 (2019)

39. C. Brix-Asala, A.K. Geisbush, P. Sauer, P. Schopflin, A. Zehendner, Sustainability tensions in supply chains: A case study of paradoxes and their management, Sustainability. 10, 424 (2018)

40. A. Ashby, M. Leat, M. Hudson-Smith, Making connections: A review of supply chain management and sustainability literature, Supply Chain Manag. 17, 497-516 (2012)

41. S. Chopra, P. Meindl, Supply chain management, $6^{\text {th }}$ ed. (Pearson Education, Inc., New York, 2016) 